\title{
Disaster Risk Reduction and Emergency Preparedness for Children With Autism in Facing Earthquake Disaster in Yogyakarta
}

\author{
Fika Nur Indriasari*, Prima Daniyati K, Linda Widyarani
}

*Correspondent Author: fheekha.nur@gmail.com

*Department of Pediatric Nursing, Akper Notokusumo, Indonesia

\begin{tabular}{l}
\hline I N D E X I N G \\
\hline Keywords: \\
Disaster Risk Reduction; \\
Preparedness; \\
Children with autism
\end{tabular}

Kata Kunci:

Pengurangan Resiko

Bencana;

Kesiapsiagaan;

Anak Auitis

\begin{abstract}
A B S T R A C T
Special Needs Children (ABK) is one of the vulnerable groups in times of disaster. Some of them have mobility hindrance even to perform a defence and personal escape independently, therefore, information is needed on what procedures or plans to take to rescue ABKs who need help from people around them (e.g. teachers, classmates, school staffs). Objectives: To determine the preparedness of children with special needs in dealing with earthquake disasters in Yogyakarta. This research uses a quasi-experiment with one-pretest-posttest design. The samples are selected using a purposive sampling technique, while the data are collected by means of observation sheets. The respondents for this research are special needs children with autism at 'SLB N Pembina', Yogyakarta. Data analysis is performed using a descriptive qualitative analysis. Disaster awareness trainings give a positive influence in reducing disaster risks and in increasing the disaster preparedness of special needs children with autism. Special needs children with autism show ability and participation after performing 5 times simulation. The preparedness increase of special needs children before and after training is $39 \%$.
\end{abstract}

$\overline{\text { Article history: Received 2018-Jan-09; Revised 2018-March-24; Accepted 2018-May-02 }}$

ABK merupakan salah satu kelompok paling rentan ketika terjadi bencana. Beberapa dari mereka memiliki hambatan mobilitas untuk melakukan perlindungan bahkan penyelamatan diri secara mandiri sehingga diperlukan adanya informasi bagaimana prosedur atau rencana penyelamatan bagi ABK yang memerlukan bantuan orang di sekitar mereka (misal: guru, teman, staf sekolah). Tujuan penelitian ini untuk mengetahui kesiapsiagaan anak berkebutuhan khusus dalam menghadapi bencana gempa bumi di Yogyakarta. Desain penelitian adalah quasi eksperimen dengan rancangan one pre post test design. Teknik pengambilan sampel dengan purposive sampel sedangkan teknik pengumpulan data dengan lembar observasi. Responden penelitian adalah anak berkebutuhan khusus dengan autis di SLB N Pembina Yogyakarta. Analisis data menggunakan analisis deskriptif kualitatif. Pemberian pelatihan siaga bencana memberikan pengaruh positif dalam mengurangi resiko bencana dan meningkatkan kesiapsiagaan terhadap bencana gempa bumi pada anak dengan autis. Peningkatan kesiapsiagaan anak-anak autis sebelum dan sesudah diberikan simulasi sebanyak $39 \%$.

(C) 2018 JMMR. All rights reserved

\section{INTRODUCTION}

Natural disasters are events or series of events which inflict victims, such as loss of belongings, destruction of the environment, destruction of infrastructures, and even loss of lives. Generally, there are three factors that cause disasters: 1) natural factors, because of natural phenomena, with or without human intervention; 2) non-natural factors, those not caused by human activities; 3 ) and social/human factors, purely because of human activities. ${ }^{1}$ One of the natural factor disasters which often strikes Indonesia is the earthquake, because Indonesia is located between Eurasia, Indo-Australia, and Pacific Ocean plates, this area is full of activities related with plates movements as well as volcanic activities, not to mention crumbling rock formations.
Earthquake is one of the many unpredictable natural disasters. This disaster destroys buildings rapidly, and can inflict injury and even death on people in affected areas. Earthquake is the movement of the earth as the result of the release of energy that has been accumulated in deformed rocks. $^{2}$

According to recorded data of epicenter distribution of earthquakes with magnitude 5 from 1900-2000, and based on the map of earthquake areas in Indonesia, Yogyakarta Special Region (DIY) is located in region 4. The region is an area which is often hit by earthquakes. Aside from the fact that DIY is located in the area where two plates meet, it also occupies the line where active volcanoes are located. Such a position makes DIY vulnerable to both tectonic and volcanic earthquakes. $^{3}$ 
DIY province, is one of the regions susceptible to serious disasters. The National Disaster Mitigation Body (BNPB) stated that DIY had experienced quakes stronger than magnitude 5 in 1867, 1943, 1976, and 2006. Based on BNPB's data (2014), the earthquake on 27 May 2006 had claimed 5,716 lives and caused 37,927 people injured. The worst impact was in Bantul Regency area, which was the area closest to the center of the earthquake, 4,143 people were killed and 12,026 were injured.

The earthquake got people, especially children and elderly people, trapped in their houses, because it happened early in the morning, and children and elderly people were unable to save themselves. This shows just how weak disaster preparedness is in Indonesia. ${ }^{4}$

One of the efforts taken by the government in Mitigating Disasters' Risks is by issuing regulations such as Law No. 24, 2007 on Disaster Mitigation, Government Regulation No. 21 of 2008 on Disaster Mitigation Organization, Government Regulation No. 28 of 2008 on Funding and Management of Disaster Aids and Internal Affairs Minister's Regulation No. 46 of 2008 on Guidelines for Organization and Working Procedures of Regional Disaster Mitigation Body. It is in this context that the plan for a Disaster Risk Reduction should be designed systematically, compact, and well-planned. This is also supported by the reality that the condition of Indonesia is marked with a high vulnerability against disasters. According to International Strategy for Disaster Reduction 2006-2009, Indonesia ranks 7 as the nation with natural disasters in 2005.

Earthquake disaster risk reduction should be implemented early on, that is, from the time of school age. This is meant so that students as part of the nation's future can reduce disaster risks which put them and people around them in danger, therefore, steps towards preparedness in dealing with earthquake disasters is essential to increase safety both in terms of life and belongings.

Various impacts caused by disasters give us a lesson that disaster preparedness education at school is important. The school is a place to develop students' knowledge and to train students to be aware of disasters and to minimize risks of disasters. The school as the place for students to study should ensure safety and protection for all of the students against any disturbances, including the threats of a disaster which might happen anytime at school. The absence of standard operating procedures (SOP) and methods of disaster mitigation would produce mishandling, and it might aggravate an already precarious situation and might affect the number of victims. ${ }^{5}$
The World Conference on Disaster Reduction held in January 2005 in Kobe, Japan, produced several basic substantial agreements in the efforts to reduce losses due to disasters, such as life loss, social loss, economic loss, and environmental loss. The basic substantial agreements need to be included as part of the commitments made by the government, regional and international organizations, society, private institutions, academics and other stakeholders. The strategies adopted to carry out the basic substantial agreements are, among others:

1. Incorporating disaster risks into policies, plans, and programs of sustainable development effectively and integrated, with a special emphasis on the prevention, mitigation, preparation and reduction of disaster susceptibility.

2. Development and reinforcement of institutions, mechanism, and capacity in every level, especially in the society, so that the society can systematically increase its resilience against disasters.

3. Systematic cooperation in disaster risk reduction, emergency preparedness implementation, and restoration program for reconstruction aimed at those affected by the disaster.

The problem of disasters involves various life dimensions, both individual and organizational, therefore, handling disaster problems needs a comprehensive approach, the same applies to building disaster awareness.

According to Irene (2008), disaster management is the basic knowledge which is related with efforts to minimize risks, which involves preparedness, support, and rebuild the society after a disaster hits. Generally, disaster management is a continual process performed by individuals, groups, and communities in managing the dangers as an effort to avoid or to reduce the impacts of a disaster. The actions taken depends on the perception about the risks being faced. The effectiveness of disaster management depends on the alignment of all the elements, both government and nongovernment. Activities in each hierarchy (individual, group, society) give influence on different levels. The cycle of disaster management consists of four stages, namely:

1. Prevention/mitigation

2. Preparedness before disaster

3. Emergency response

4. Rehabilitation and reconstruction after disaster.

Disaster preparedness is defined as actions taken to increase life safety during a disaster. Preparedness also includes actions which are designed to increase the ability to 
protect properties from damage and chaos in the event of a disaster and the ability to be involved in early restorative and renovative activities after a disaster. ${ }^{6}$

Several main causing factors of the many victims in a disaster in community's lack of knowledge about disasters and lack of preparedness in anticipating the disasters. In the case of earthquakes, the many casualties are due to collapsing structures. Among the casualties, most are women and children. ${ }^{7}$

Children are one of the vulnerable groups at risk of disasters' impacts (Government Regulations No. 21, 2008). Lopez et al. (2012) stated that children's involvement in disaster management gives a positive contribution to the disaster rescue, restoration, and rehabilitation. Children's involvement is a component in disaster risk reduction. ${ }^{8}$

A safer school is essential to protect children's lives during a disaster. The concept of school safety is not limited in preventing the collapse of the school building in a disaster and the safety of teachers and students, but also includes a bigger scope of "disaster risk management", because children are the next generation. What the children learn about safety today will be beneficial in the development of a "disaster risk responsive society" in the long run. This is where disaster education plays an important role in school safety. ${ }^{9}$

A strategic step that can be taken is by providing training to educational institutions, especially school communities. There are several materials that can be given as a training, such as mitigation techniques and earthquake disaster management. The mitigation techniques include preearthquake disaster mitigation or early phase of risk reduction, self-protection efforts during earthquake disaster, and evacuation after the earthquake ends accompanied by first aid to victims. ${ }^{3}$

Giwangan sub-district is located in the south of Yogyakarta city, it shares borders with Bantul Regency area, which is susceptible to earthquakes. According to the map of the 2006 earthquake destruction, Giwangan belongs to moderate damage area. There is one Special Needs School in Giwangan sub-district, it has 230 students. Special needs children are the most vulnerable group in an event of disaster. Some of them have mobility hindrances to obtain protection, even for an independent self-rescue, therefore, information is needed regarding rescue procedures or plans for special needs children who are dependent on the people around (such as teachers, classmates, school staffs). Based on a preliminary study conducted by the researcher on several elementary school teachers around Giwangan subdistrict, it is found that students and teachers had a training on disaster awareness once after the earthquake of 2006 in Yogyakarta, but there has never been any other similar training after that, because the training was part of a project funded by the government.

\section{RESEARCH METHOD}

This research is a observational descriptive design. Data analysis is performed using a descriptive qualitative analysis. The research is conducted from January November 2017. The research location is SLB N Pembina, Yogyakarta, with a population of 230 students.

The samples were selected by considering students' data at SLB N Pembina, Yogyakarta, with the following inclusion criteria: autistic; not suffering from any diseases; and willing to participate as a respondent. Whereas the exclusion criteria is: absence during the time of intervention. The instruments used in this research are: a disaster awareness simulation video; earthquake simulation checklist; and a flipchart containing materials on disaster awareness. The disaster awareness video's duration is 20 minutes and is divided into five scenes that show correct and incorrect actions to be taken during an earthquake disaster. Data analysis for this research uses a descriptive qualitative method.

\section{RESULT AND DISCUSSION}

Autism is a group of symptoms (syndrome) caused by neural damage. The symptoms are evident before the child reaches the age of three years. Autistic children show symptoms of impaired communication. This communication disorder can be seen in the form of delayed speech, speaking disability, indiscernible speech, or speech repetition (echolalia). Other than communication disorders, autistic children also show interaction problems with people around them, either adults or peers. ${ }^{10}$

Almost all children with autism have characters which direct towards communication and social interaction disorder. Such behaviors can emerge anytime depending on the child's condition when receiving a stimulation from the surrounding. Based on characteristics stated by several experts, autistic children's characteristics emphasize on disregarding social environment, not reacting normally in social interaction, performing repetition in reaction, not having confidence in self, showing aggressive attitudes, and giving lack of or over response to stimuli. ${ }^{11}$ 
Table 1. Distribution of Frequency of Autistic Children Based on Age and IQ at SLB N Pembina Yogyakarta Tahun 2017 (n=23)

\begin{tabular}{|c|c|c|c|c|c|c|c|c|c|}
\hline \multirow[t]{2}{*}{$\begin{array}{c}\text { No } \\
\text { • }\end{array}$} & \multirow[t]{2}{*}{ Category } & \multicolumn{2}{|c|}{$\begin{array}{c}\text { Low } \\
\text { IQ }\end{array}$} & \multicolumn{2}{|c|}{$\begin{array}{c}\text { Mediu } \\
\text { m } \\
\text { IQ }\end{array}$} & \multicolumn{2}{|c|}{$\begin{array}{c}\text { High } \\
\text { IQ }\end{array}$} & \multicolumn{2}{|c|}{ Total } \\
\hline & & $\mathbf{n}$ & $\%$ & n & $\%$ & $\mathbf{n}$ & $\%$ & $\mathbf{n}$ & $\%$ \\
\hline 1 & Gender & & & & & & & \multirow{3}{*}{$\begin{array}{l}2 \\
3\end{array}$} & \multirow{3}{*}{$\begin{array}{c}10 \\
0\end{array}$} \\
\hline \multirow{4}{*}{2} & Males & 6 & $\begin{array}{c}26, \\
1\end{array}$ & 6 & $\begin{array}{c}26, \\
1\end{array}$ & 8 & $\begin{array}{c}34, \\
5\end{array}$ & & \\
\hline & Females & 2 & 8,7 & 0 & 0,0 & 1 & 4,3 & & \\
\hline & Education & & & & & & & & \\
\hline & Level & & & & & & & & \\
\hline & Elementar & 2 & 8,7 & 0 & 0,0 & 4 & 17, & & \\
\hline & $\mathrm{y}$ & & & & & & & 2 & 10 \\
\hline & $\begin{array}{l}\text { Junior } \\
\text { HS }\end{array}$ & 3 & $\begin{array}{c}13, \\
0\end{array}$ & 3 & $\begin{array}{c}13, \\
0\end{array}$ & 3 & $\begin{array}{c}13, \\
0\end{array}$ & 3 & 0 \\
\hline & $\begin{array}{r}\text { High } \\
\text { School }\end{array}$ & 4 & $\begin{array}{c}17, \\
4\end{array}$ & 2 & 8,7 & 2 & 8,7 & & \\
\hline
\end{tabular}

The description of respondents' characteristics can be seen in Table 1, namely, the overall number of respondents is 23 children. The classification of special needs children with autism at 'Pembina' State Special Needs School consists of 3 characteristics: high IQ; medium IQ; and low IQ. Respondents in this research with high IQ are 7 male children (30.4\%) and 2 female children (8.7\%). Respondents with medium IQ are 6 male children $(26.1 \%)$ and no female children. Respondents with low IQ are 7 male children (30.4\%) and 1 female child (4.3\%).

There are 2 respondents from high IQ group with elementary school education $(8.7 \%) ; 3$ respondents with secondary school education (13\%); and 4 respondents with high school education (17.4\%). In medium IQ group, there is no respondent with elementary education $(0 \%) ; 3$ respondents with secondary school education (13\%); and 2 respondents with high school education (8.7\%). In low IQ group, there are 4 respondents with elementary education $(17.4 \%) ; 3$ respondents with secondary school education (13\%); and 2 respondents with high school education $(8.7 \%)$.

In this research, respondents' characteristics based on gender is dominated by males, that is, 20 children, and the number of female respondents is 2 . Autism can happen to children of various social strata and various cultures. Survey results taken from several countries show that 2-4 per 10,000 children are susceptible to develop autism, and the ratio between males and females is $3: 1 .^{12}$ This is supported by Gamsiz, et al (2013) in their research, which stated that male children tend to be more vulnerable to experience nervous system development disorder, including autism, than female children. And the risk of autism when having siblings with autism is $3 \%$. Another study shows that twin siblings of the same gender who are monozygotic have 300 times greater risk than dizygotic of developing autism. ${ }^{13}$

Vulnerability to develop nervous system disorder among male and female children is caused by gene. Some scientists who performed researches on autism found differences in the brain part which gives signals in learning and motivation, this makes male children more vulnerable to autism genes. Another research also revealed that males who carry the $\mathrm{X}$ chromosomes that have experienced specific alteration have a high risk of developing autism spectrum. Male children inherit one $\mathrm{X}$ chromosome from the mother and one Y chromosome from the father. If a male child's X chromosome loses the PTCHD1 gene or any other closest DNA string, he has a high risk of developing autism or even intellectual disability. However, female children are different in this matter. Female children have two $\mathrm{X}$ chromosomes, therefore, when one of the chromosomes loses the PTCHD1 gene, they always have the second X chromosome. Researchers believe that PTCHD1 genes play a role in delivering information to the cells when the brain is developing. Mutation of the PTCHD1 gene in the $\mathrm{X}$ chromosome contributes in the development of autism. ${ }^{14}$

According to Nature Genetics Journal's report, neurexin genes found in human chromosome no. 11 is one of the genes that plays an important role in the incidence of autism syndrome. Neurexin is a protein which plays a role in assisting neural cells communication. One of the proteins from the neurexin family coded by CNTNAP2 (Contactin Associated Protein-like 2) genes functions as the receptor molecule in neural cell. In the womb, when the fetus' blood sample is taken and analyzed, autistic children experience protein increase in the blood, that is, three times higher than normal children. ${ }^{15}$

According to experts, genes that are currently associated with autism, actually are also related with genes that increase a person's intelligence level or IQ. Most autistic children are considered as unable to follow lessons or to respond to a conversation, because they experience mental retardation. While actually, a study has confirmed that autistic individuals actually have a high level of intelligence. This was proved in a research which asked 10,000 participants to take part in a series of IQ tests. The results showed that those who carry the gene variant similar to the one found in autistic persons have higher score than those who do not have such a gene. Another researcher, 
Prof. Nick Martin from Queensland Institute for Medical Research said that the gene which carries autism actually can give intellectual "advantages" to anyone who has it, as long as they do not catch the condition (autism). Even so, experts are yet to precisely determine how to explain the mechanisms in both instances. ${ }^{16}$

Based on the classification, there are three characteristics of special needs children with autism at 'Pembina' Special Needs School, high IQ; medium IQ and low IQ. Pusponegoro and Solek (2007) mentioned that autistic children's intelligence level is divided into three parts, namely 1) low functioning (low IQ), if someone belongs to the category of low IQ, it is expected that later in life, he/she cannot live independently, he/she will be reliant on others; 2) medium functioning (medium IQ), if someone belongs to the medium IQ category, he/she can still maintain a social life, and he/she can still attend the special school intended for autistic children; 3) high functioning (high IQ), if someone belongs to the high IQ category, he/she will probably be able to live independently, even succeed in his/her life, or build a family. ${ }^{17}$

Intelligence is someone's capacity to take planned actions; to think rationally; and to maintain an effective relation with the environment. Intelligence is measured with the help of a psychological test, and the end result unit is well-known as IQ (intelligence quotient). IQ is the number that explains the level of someone's intelligence as compared with others' in a population. IQ test aims to assess a child's intelligence when: IQ is a ratio of mental age divided by physical age, times 100 . Mental age is counted based on the average result of a test which is distributed into age categories. IQ composition consists of several aspects grouped into 2 main categories: verbal IQ and non-verbal IQ. Autistic children who normally experience disturbances in their language development must have low verbal IQ. This is unfair if they are then judged as having a mental retardation. One of the more accurate tests to be used is the non-verbal IQ assessment. Non-verbal IQ represents the abilities that are not related with language, it indicates one's capacity to function effectively, rationally and planned. Non-verbal intelligence is divided into 2 ability strata: low order skills, the skills that are associated with processes of interpretation, organization, and manipulation of symbolic and concrete characters of stimuli (such as size, color, shape, and texture); and high order skills, the skills that are more characterized with problem solving and abstract rationalizing.

Classification of autistic children based on intellectual features is as follows: 1) autism with medium and severe mental retardation (IQ below 50), with $60 \%$ prevalence among all autistic children; 2) autism with mild mental retardation (IQ between 50-70) with 20\% prevalence among all autistic children; 3) autism with no mental retardation (IQ above 70 ) with $20 \%$ prevalence among all autistic children. ${ }^{18}$

It is estimated that around $75-80 \%$ autistic persons have mental retardation (IQ $<70$ ), while around $20 \%$ of them have sufficiently high capability in certain fields. Autistic children have problems in communication; social interaction, sensory perception; play patterns; behaviors; and emotion. In mental status assessments, there are cases of lack of environmental orientation, low memory of new events. Autistic persons usually speak fast without meaning, sometimes even followed by unintelligible mumble. Generally, autistic children's intelligence is low, however, $20 \%$ of autistic children still have IQ $>70 .{ }^{19}$

Autistic children do not seem interesting and intelligent, however, when assessed using standardized tests, their intellectual development tend to be below normal. Three out of four show signs of mental retardation. Those whose intelligence functions on an average stage still show deficits in activities which demand symbolization skills such as identifying emotion, participating in symbolic games, and solving problems conceptually. Moreover, autistic children also show difficulties in performing tasks which involve interactions with others. Even so, the correlation between autism and intelligence is actually unclear, because there is a difficulty to perform an IQ test on autistic children. Intelligence testing requires cooperation, a skill which is not owned by autistic children. The most possible thing to perform is just by estimating their intellectual capability. ${ }^{20}$

Intelligence is closely related with someone's ability to adapt to the environment, either physically or nonphysically. Intelligence is the ability to controllably act, rationally think, and effectively deal with the environment. When talking about autistic children's ability to think or intelligence, in developed countries there are many cases of autistic children who grow up becoming independent and successful individuals. Not all children with autism have low intelligence. Some have average, normal, even above average, or superior intelligence. The categories of intelligence are grouped based on psychological examination or intelligence inherited from parents. Psychological examination aimed at determining autistic children's IQ cannot be performed by any person, because performing such an examination is totally different from that for normal children. There needs special skills and special stages. 
Disaster awareness education can be given early through a program of disaster awareness at school so that children can be aware of the ways to save themselves in times of a disaster. ${ }^{21}$ Education and training of disaster management aims to increase preparedness to deal with and to manage natural disasters. ${ }^{22}$

Diagram 1. Ability and Involvement of Children in Disaster Awareness Simulation at SLB N Pembina Yogyakarta, Year $2017(\mathrm{n}=\mathbf{2 3})$

Ability and Involvement of Children in Disaster Awareness Simulation

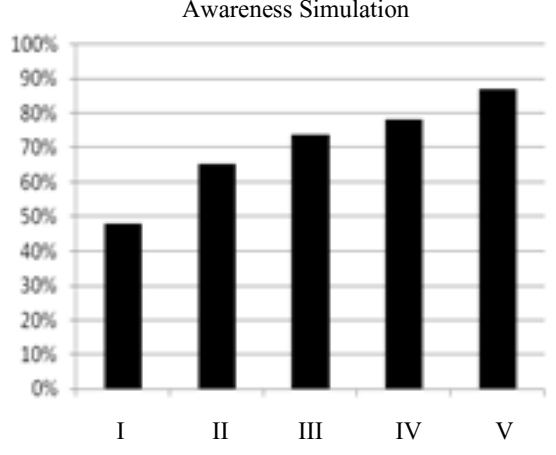

The children's involvement and ability in performing the simulation show an increase to $87 \%$ after simulation was performed five times. This is in line with the objective of the research, that is, to provide an education on disaster awareness to autistic children, and the target of the children's aptitude to be able to help themselves is achieved. $^{21}$

In this research, the training of disaster awareness for children uses lecture and simulation. The role of simulations in disaster management in assessing one's readiness to deal with disasters. ${ }^{23}$ According the other research also stated that the education about disaster awareness using simulations in the form of games or activities can give better results compared to without using simulations. ${ }^{24}$

Simulation is a way to present a learning experience by using mock up situations to understand about certain concepts, principles, or skills. Simulation can be used as a learning method with an assumption that not all learning process can be performed directly on the actual objects. ${ }^{25}$ Statistically, this research shows that by using an earthquake disaster awareness simulation method, autistic children's involvement in the simulation is proven to increase. The simulation method is proven effective to be applied for autistic children, compared with interview and picture method. The materials conveyed using a simulation method will facilitate children to accept and understand the lesson, because they can virtually perform like in the real event, and it can give a direct experience for the children and will increase their interest and spirit to learn, therefore, children are more willing to follow the lesson and get the desired result. ${ }^{26}$ The Other research stated that games/ activities that involve pictures, simulation and demonstration about earthquake disaster mitigation are effective to increase understanding about earthquake disaster mitigation and also stated that the simulation method is an effective method to be applied to autistic children. Results of their research show that the simulation method is effective to be applied to autistic children to recognize the toilet/bathroom; to learn about the use and the way to use of things available in the toilet/bathroom. ${ }^{27,28}$

The simulation performed includes seven motions, including head and neck protecting and walking towards the assembly point. During each motion, the children's responses include fear, screaming and crying, but there are three children who seem to be oblivious about the situation. Autistic children who are unresponsive and ignorant belong to unsociable and passive group, whereas those who scream and cry, ${ }^{18}$ the other research also stated that the children with a high risk of mental health disturbance during a disaster setting. They need to be given protection and help due to their lack of development, lack of coping skills, and inability to understand an event. These children's thoughts can come to the wrong interpretation and they might not have the verbal ability to describe their experience. ${ }^{29}$

Children with Autism Spectrum Syndrome (ASD) have difficulties in focusing on what is in front of them. ASD is a brain-based condition where the brain has not developed in a typical way. ASD patients are having troubles in making social contact with others, they usually take longer than other children to learn a language, and often find it hard to make sense of language, so understanding simple instructions and social norms can be difficult. Based on the above characteristics of ASD, the method of disaster event simulation is an effective disaster risk reduction method for children with ASD. The disaster event simulation which mimics the real event would provide a real learning experience for children with ASD, because learning the theory alone without any practice/simulation would not be able to develop appropriate response from a child with ASD in the event of a real disaster. Disaster preparedness simulation which imitate the real disaster event would also develop ASD children's ability to communicate verbally and non-verbally, to show reactions through skills and to socially participate with others. ${ }^{30}$ 
In this research, the disaster simulation performed also involved parents or other family members. The involvement and support from parents or other family members gave a positive influence, because the child became actively physically involved in the disaster simulation, not just quietly looking, and not participating. This is consistent with what was stated by Memari et al. (2015) that closeness and support from parents and family members gives a positive impact on the participation and involvement of the child with ASD in the learning activities at school, children with ASD who have closeness with parents/family members, often take recreations together, accompanied to and from school, or engage in other activities, show better abilities. ${ }^{31}$

The learning media used in this research is an audio visual material, it's a video of disaster awareness. The presentation of the content to the children will be more complete and optimal by using such a medium. ${ }^{17}$ The simulation methods can be in the form of film/video media; game therapies; and/or field practices/exercises, the simulation method using film/ video media is proven as the most effective to be applied for autistic children. ${ }^{32}$

Video is considered effective as the learning media for children with autism, because it can trigger spontaneous verbal reactions, such reactions are normally performed by parents or surrounding people, such as teachers or classmates. Learning through video also triggers the children's willingness to engage in a two-way communication with others, such as with parents, teachers, and classmates. $^{33}$

This is consistent with the results of this research that when the disaster simulation video finished, and the teacher/tutor ask about the things to do when an earthquake strikes, respondents spontaneously give responses well, which means that the video brings a positive impact to the vocalization ability and communication in autistic children.

In this research, the simulation video has a duration of 20 minutes, the duration was chosen because if it is very long, it would exceed the respondents' concentration span, the video is also played repeatedly so that respondents understand the content well. Video playing as a learning method for children with autism needs to be performed repeatedly with a short duration, simple dialogs, and clear audio so that the children's focus can be maintained and boredom can be prevented. ${ }^{34}$

Observation results show that most of the children are enthusiastic to watch the video until finish. The audio visual animated media can increase children's skills to focus and they also increase children's learning interests. ${ }^{35}$
The level of success in teaching and educating autistic children is influenced in part by how severe the level of autistic symptoms experienced by the child, severely autistic children will need more time achieving the success compared to those with milder disorder. Therefore, the milder the autistic disorder a child has, the higher the possibility and the faster it is for him/her to achieve success. $^{36}$

\section{CONCLUSION}

The use of a simulation method earthquake disaster awareness training gives a positive influence on the autistic children's preparedness. These autistic children get actively involved, and after doing five simulation repetitions, reach $87 \%$ earthquake disaster awareness ability. Before training is given, these autistic children's involvement was $48 \%$, and after the simulation their involvement is $87 \%$.

\section{REFERENCE}

1. Nurjanah,dkk. (2012). Manajemen Bencana. Bandung: ALFABETA

2. Noor, Djauhari. (2011). Geologi Lingkungan. Yogyakarta: Graha Ilmu.

3. Dwisiwi, R.S, Surachman, Sudomo, J \& Wiyatmo, Y. (2012). Pengembangan Teknik Mitigasi Dan Manajemen Bencana Alam Gempabumi Bagi Komunitas SMP DI Kabupaten Bantul Yogyakarta. Prosiding Seminar Nasional Penelitian. Pendidikan dan Penerapan MIPA. Fakultas MIPA. Universitas Negeri Yogyakarta

4. Rinaldi. (2009). Kesiapan Menghadapi Bencana Pada Masyarakat Indonesia. Universitas Negeri Padang. Jurnal Penelitian Psikologi 14(1)

5. Muller, J. C. Y. (2014). Adapting to Climate Change and Addressing Drought-Learning from the Red Cross Red Crescent Experiences in the Horn of Africa. Weather and Climate Extremes, 3, 31-36.

6. Sutton. J \& Tierney. K. (2006). Disaster Preparedness: Concepts. Guidance. and Research. Institute of Behavioral Science University of Colorado.

7. Pribadi, K.S \& Yuliawati, A.K. (2008). Pendidikan Siaga Bencana Gempa Bumi Sebagai Upaya Meningkatkan Keselamatan Siswa. http://jurnal.upi.edu/file/KRISHNA_S_PRIBADI__ITB.pdf. diakses : 20 Februari 2017

8. Lopez, Y., Hayden, J., Cologon, K \& Hadley, F. (2012). Child participation and disaster risk reduction. Int $J$ Early Years Educ,20(3), 300-308

9. UNCRD. (2009). Mengurangi Kerentanan Anak-anak Sekolah terhadap Bahaya Gempa Bumi. Proyek Inisiatif Keselamatan Sekolah Terhadap Gempa Bumi (SESI). UNCRD 
10. Maulana, Mirza. (2007). Anak Autis: Mendidik Anak Autis dan Gangguan Mental Lain. Yogyakarta: Ar-Ruzz Media Group.

11. Rahayu, Fitri. (2014). Kemampuan Komunikasi Anak Autis dalam Interaksi Sosial. Yogyakarta: Universitas Negeri Yogyakarta.

12. Harizal, Novery. (2011). Gambaran Tingkat IQ terhadap Kemajuan Terapi Anak Autisme di SLB Bima Kota Padang Tahun 2011. Padang : Universitas Andalas.

13. Gamsiz, E.D, et al. (2013). Intellectual Disability Is Associated with Increased Runs of Homozygosity in Simplex Autism. The American Journal of Human Genetics (93)

14. Fitriyani. (2018). Penelitian : Alasan Mengapa Autisme Sering Terjadi Pada Anak Laki-Laki. The Asian Parent Indonesia. URL: https://id.theasianparent.com/penelitiantentang-autisme-pada-anak-laki-laki/

15. Winarno. (2013). Autisme dan Peran Pangan. Jakarta: Gramedia.

16. Edinburgh. (2018). Studi: Gen Pembawa Autis Juga Pengaruhi Tinggi IQ Anak. URL: https://health.detik.com/anak-dan-remaja/2856770/studi-genpembawa-autis-juga-pengaruhi-tinggi-iq-anak

17. Pusponegoro, H D. Solek, Purboyo. (2007). Apakah Anak Kita Autis?. 1st Ed. Bandung: Trikarsa Multi Media.

18. YPAC. (2013). Buku Pedoman Penanganan dan Pendidikan Autisme YPAC. Yayasan Autisme Indonesia.

19. Yatim, Faisal. (2003). Autisme: Suatu Gangguan Jiwa Pada Anak-Anak. Jakarta : Pustaka Populer Obor.

20. Nevid, J., Rathus, S., \& Greene, B. (2006). Psikologi Abnormal (jilid 2). Jakarta: Erlangga.

21. Suhardjo, D. (2011). Arti Penting Pendidikan Mitigasi Bencana Dalam Mengurangi Resiko Bencana. Cakrawala Pendidikan, Juni, Th. XXX, 2.

22. BNPB. (2012). Pengembangan Kurikulum Pendidikan Dan Pelatihan Berbasis Kompetensi. Jakarta: BNPB.

23. Steward, D \& Wan, T.T. (2007). The Role of Simulation and Modeling in Disaster Management. J Med Syst. 3, 125-130.

24. Olson, D.K, Scheller, A, Larson, S, Lindeke, L \& Edwardson, S. (2010). Using Gaming Simulation to Evaluate Bioterrorism and Emergency Readiness Education. Public Health Rep, May-June 2010, 125, 468-477.

25. Sanjaya, W. (2013). Strategi Pembelajaran: Berorientasi Standar Proses Pendidikan. Jakarta: Kencana Prenadamedia Group.
26. Yanti, E, (2015). Efektifitas Metode Simulasi Dalam Meningkatkan Kemampuan Bina Diri Bagi Anak Autis. Jurnal Ilmiah Pendidikan Khusus, Vol 4, No.3.

27. Kurniawan, R, Mahtarahmi, A \& Rakhmawati, R. (2017). GEMPA: Game Edukasi sebagai Media Sosialisasi Mitigasi Bencana Gempa Bumi bagi Anak Autis. JNTETI, Vol. 6, No. 2.

28. Ramachandiran, C.R., Jomhari, N., Thiyagaraja, S., Maria, M. (2015). Virtual Reality Beased Behavioural Learning for Autistic Children. The Electronic Journal of e - Learning. Volume 13 Issue 5. pp : $357-365$.

29. Coffman. (1998). Children's Reactions to Disaster. J Pediatr Nurs, 13(6), 376-82.

30. Fino, R., Lin, M.J., Caballero, A., Balahadia, F.F. 2015. Disaster Awareness Simulation for Children with Autism Spectrum Disorder Using Android Virtual Reality. Journal of Telecommunication, Electronic and Computer Engineering. Vol. 9, pp: 2-6

31. Memari, A.H., Panahi, N., Ranjbar, E., Moshayedi, P., Shafiei, M., Kordi, R., Ziaee, V. 2015. Children with autism spectrum disorder and patterns of participation in daily physical and play activities. Neurology Research Internasional. Vol. 5, pp: 1-7

32. Kajganich, G. (2013). Simulation to Build Empathy in Adolescents With Autism Spectrum Disorders: a Video Modeling Study. Kanada: University of Ottawa. Dikutip dari: https://ruor.uottawa.ca/bitstream/10393/24258/1/Kajganich_G illian_2013_thesis.pdf

33. Corbett, B,A., Abdullah, M. 2005. Video Modeling: Why does it work for children with autism?. JEIBI. Vol. 2. Issue No. 1.

34. Courey, S., LePage, P. 2011. Filmmaking: A video-based intervention for developing social skills in children with autism spectrum disorder. Interdisciplinary Journal of Teaching and Learning. Vol. 1. No. 2, p: 88-103

35. Karimah, Y. (2009). Peningkatan Keterampilan Menyimak Cerita Anak melalui Media Animasi Audio Visual pada Siswa Kelas VI SDI I Ma'had Islam Pekalongan. Tesis: Universitas Negeri Semarang

36. Azwandi, Yosfan. (2005). Mengenal dan Membantu Penyandang Autisme. Jakarta: Departemen Pendidikan Nasional. 